підприємництва України: стратегія та механізм зміцнення: Монографія. / Т.Г. Васильців - Львів: Арал, 2008. - 384 с.

\section{9. Прохорова}

В.В. Управління економічною безпекою підприємств: [Монографія] / В.В. Прохорова, Ю.В. Прохорова, О.О. Кучеренко; [Українська державна академія залізничного транспорту]. - Х.: УкрДАЗТ, 2010. - 283 с.

10. Франчук В.І. Основи економічної безпеки: навч. посіб. / В.І. Франчук. - Львів. держ. ун-т внугр. справ. - Львів: Каменяр, 2009. - 203 с.

11. Кожевников Р.А. Экономическая безопасность железнодорожного трансопрта: Учебник для вузов ж.-д. транспорта / Р.А. Кожевников, 3.П. Межох, Н.П. Терешина и др. М.: Маршрут, 2005. - 326 c.

12. Костюк Ж.С. Сутність поняття «Економічна безпека підприємств залізничного транспорту» / Ж.С. Костюк // Вісник економіки транспорту і промисловості. - 2013. - №41. - С. 173-179.

13. Планування діяльності підприємства [Електронний ресурс]. - Режим доступу: http://labook.com.ua/book_planuvannya-diyalnostipidpriyemstva_849/6_nedoliki-reaktivnogoplanuvannya. - Назва з екрану.

14. Стратегічне планування як головна умова функціонування підприємства [Електронний ресурс]. http://pidruchniki.com/13820328/menedzhment/strateg ichne_planuvannya_golovna_umova_funktsionuvanny a_pidpriyemstva. - Назва з екрану.

15. From Reactive to Proactive Management [Electronic Resource]. - Mode of access: http://www.mindtools.com/pages/article/reactiveproactive-management.htm. - Title from the screen.

16. Раздина Е.В. Экономическая безопасность: сущность и тенденции развития: Автореферат дис. ... канд. экон. наук: 08.00.01.
МГУ им. М.В. Ломоносова./ Е.В. Раздина - М., 1998. -22 c.

17. Камлик M.I. Економічна безпека підприємницької діяльності. Економіко-правовий аспект: Навч. посіб. / M.I. Камлик - К.: Атіка, 2005. $-431 \mathrm{c}$.

18. Економічна безпека: навч. посіб. / за ред. 3.С. Варналія. - К.: Знання, 2009. - 647 с.

19. Забродский В. Теоретические основы экономической безопасности отрасли и фирмы / В. Забродский, Н. Капустин // Бизнес-информ. 1999. - № 13. - С. 35-37.

20. Иванов А.В. Экономическая безопасность предприятий / А.В. Иванов, В.В. Шлыков - М.: Вираж-Центр, 1995. - 40 с.

21. Гетьман О.О. Економічна діагностика: Навч. посіб. для студентів ВНЗ / О.О. Гетьман, B.M. Шаповал - Київ: Центр навчальної літератури, 2007. - 307 с.

22. Козаченко Г.В. Економічна безпека підприємства: сутність та механізм забезпечення: Монографія / Г.В. Козаченко, Р.П. Пономарьов, О.М. Ляшенко - К.: Лібра, 2003. - 280 с.

23. Іванілов О. С. Економіка підприємства: підруч. [для студ. вищ. навч. закл.] / О. С. Іванілов - К.: Центр учбової літератури, 2009. - 728 с.

24. Економічна енциклопедія: У трьох томах / Редкол.: С.В. Мочерний (відп. ред.) та ін.. К.: Видавничий центр «Академія», 2000. - 864 с. T. 1.

25. Зайцева I.Ю. Економіко-організаційні основи захисту підприємств автотранспорту від недружніх поглинань: Монографія / І.Ю. Зайцева Харків: УкрДАЗТ, 2011. - 427 с.

26. Кашин А.В. Экономическая безопасность предприятия: управленческие проблемы / А.В. Кашин // Экономика управления. - 2008. - №1.- C. 11-12.

Експерт редакційної колегії к.е.н., доцент УкрДУЗТ Назаренко І.Л.

УДК 305.81: 602

\title{
МОДЕЛЬ ЕКОНОМІКИ ТА УПРАВЛІННЯ ГОСПОДАРСТВОМ ПАСАЖИРСЬКИХ ПЕРЕВЕЗЕНЬ ЗАЛІЗНИЧНОГО ТРАНСПОРТУ
}

\author{
Котик В.О., к.е.н., доцент, \\ Котик В.В., к.е.н., доцент (УкрДУЗТ)
}

Збитковість пасажирських перевезень залізничного транспорту з кожним роком збільшується в наслідок як об'єктивних так і суб'єктивних причин. У зв'язку з ичим в статті авторами виконано огляд праць вітчизняних $i$ зарубіжних вчених по досліджуваній проблемі. Обгрунтовано теоретичні, методологічні та методичні підходи і конщептуальні засади щзодо вдосконалення діючої системи управління збиткових пасажирських перевезень залізничного транспорту та поступового вирішення питань їх фінансування за рахунок механізмів державного втручання.

(C) Котик B.O.,

Котик В.В.
Вісник економіки транспорту і промисловості № 50, 2015 
Ключові слова: залізничний транспорт, пасажирські перевезення, ивидкісний рух.

\title{
МОДЕЛЬ ЭКОНОМИКИ И УПРАВЛЕНИЯ ХОЗЯЙСТВОМ ПАССАЖИРСКИХ ПЕРЕВОЗОК ЖЕЛЕЗНОДОРОЖНОГО ТРАНСПОРТА
}

\author{
Котик В.А., к.э.н., доцент, \\ Котик В.В., к.э.н., доцент (УкрГУЖТ)
}

\begin{abstract}
Убыточность пассажирских перевозок железнодорожного транспорта с каждым годом увеличивается вследствие как объективных так и субъективных причин. В связи с этим в статье авторами выполнен обзор работ отечественных и зарубежных ученых по исследуемой проблеме. Обосновано теоретические, методологические и методические подходы и концептуальные основы относительно усовериенствования действующей системы управления убыточных пассажирских перевозок железнодорожного транспорта и постепенного решения вопросов их финансирование за счет механизмов государственного вмешательства.
\end{abstract}

Ключевые слова: железнодорожный транспорт, пассажирские перевозки, скоростное движение.

\section{MODEL OF ECONOMY AND MANAGEMENT BY ECONOMY OF PASSENGER TRANSPORTATIONS OF RAILWAY TRANSPORT}

\author{
Kotik V.A., candidate of economic science, associate professor, \\ Kotik V.V., candidate of economic science, associate professor (USU of RT)
}

The unprofitableness of passenger transportations of railway transport with every year increases because of both objective and subjective reasons. In this connection in the article authors are execute the review of works of home and foreign scientists on investigated issue. Theoretical, methodological and methodical approaches and conceptual bases are reasonable in relation to the improvement of operating control system of unprofitable passenger transportations of railway transport and gradual decision of questions their financing due to the mechanisms of state interference. Advantages and lacks of functioning of passenger railway transport are exposed in the world. Factors impedimental to development of speed and high-speed motion and the chronologic models of their development are worked out in the world are classified.

Keywords: railway transport, passenger transportations, speed motion.

Постановка проблеми. У сучасних умовах роль і місце чинників підвищення ефективності функціонування пасажирських перевезень залізничного транспорту України визначається ступенем реалізації та впровадження науковотехнічного прогресу. Оживлення економіки України пред’являє принципово нові підходи щодо якості надання послуг залізницями.

Даний період часу характеризує зародження нового інформаційного суспільства у якому соціальні потреби населення мають бути пріоритетними. Ці потреби впливають на побудову i розвиток економічної системи державного регулювання функціонування пасажирських перевезень.

Аналіз останніх досліджень і публікацій. Значний вклад у розробку теорії державного регулювання внесли такі вчені економісти, як: К. Макконел, А. Маршал [1], Л. Рхад, Дж. Стігмець, В. Ойкне, А. Ханцен, М. Фрідмен [2]. Питанням розробки методології державного регулювання економічних процесів в умовах ринкової економіки присвячено роботі таких вчених економістів, як Л.І. Абалкіна, В.П. Бабіча
[3], I.I. Лукінова [4]. Проблемами формування i розвитку соціальної інфраструктури на державному і регіональному рівні займались такі українські вчені: .В. Бєлов, В.Г. Галабурда, М.Ф. Трихунков, М.С. Мандриков, Н.В. Терьошина, Н.Г. Смєхова, М.М. Толкачева, Р.М. Царьов [5]. На залізницях державним регулюванням підвищення ефективності пасажирських перевезень у різний термін часу займались такі вчені - економісти, як: О.Г. Дейнека, В.Л. Дикань, Л.О. Позднякова [6], Ю.С. Бараш [7], Т.О. Мукмінова [8].

Проте роботи зазначених вчених не охоплюють усю проблематику та глибину складних, 3 економічної точки зору, та суперечливих процесів, що виступають соціальними наслідками ринкової трансформації вітчизняної економіки.

Виділення невирішених частин загальної проблеми. Світовий досвід свідчить про те, що соціальна ефективність ринкових перетворень неможлива без створення ефективної системи державного регулювання сталого функціонування пасажирських перевезень. Ці обставини саме i 
передбачають необхідність розробки нових механізмів державного регулювання та управління 3 використанням механізмів стратегічного планування i прогнозуванням структури пасажирського господарства залізничного транспорту України. Зазначене обумовило вирішення основних задач дослідження.

$$
\text { Метою статті } \epsilon \text { обгрунтування }
$$
теоретичних, методологічних та методичних підходів і концептуальних засад щодо вдосконалення діючої системи управління збиткових пасажирських перевезень залізничного транспорту та поступового вирішення питань їх фінансування за рахунок механізмів державного втручання.

Викладення основного матеріалу. Збитковість пасажирських перевезень залізничного транспорту України, що $\epsilon$ характерним для аналогічних перевезень усіх залізничних адміністрацій країн світу 3 кожним наступним роком збільшується в наслідок як об'єктивних так і суб' єктивних причин. Ці обставини передбачають пошук економічного механізму оптимального поєднання інвестування основної складової соціальної інфраструктури державними (бюджетними) та недержавними коштами. При цьому соціальні протиріччя у сфері інвестування державою та іншими джерелами потребують невідкладних наукових досліджень. Доцільність зазначених досліджень обумовлюється необхідністю прийняття економічних рішень щодо реалізації Державної Концепції реформування залізничного транспорту України.

Технічне переоснащення галузі дозволить, на підставі придбання рухомого складу та інших технічних засобів нового покоління, забезпечити: підвищення продуктивності рухомого складу до $20 \%$, скорочення витрат енергоресурсів на 25\%, зменшення металомісткості на $10 \%$, збільшення вантажопідйомності на 7\%, скорочення витрат на ремонт до 15\%. Удосконалення системи використання інвестицій обумовить створення чіткої системи керування ними, перегляду та приведення у відповідність до ринкових умов господарювання нормативної бази організації управління, планування та регулювання, здійснення поступового переходу до переважно проектного підходу до менеджменту інвестиційних ресурсів, забезпечення рентабельної діяльності відповідних підрозділів та підвищення якості та конкурентоспроможності послуг.

Виконаний аналіз, дозволив встановити те, що на залізницях України має місце високий ступень зносу основних фондів галузі, що спонукає підвищення витрат на їх поточне утримання, ремонт та обумовлює загрозу втрати технологічної стійкості. За останні роки знос основних виробничих фондів зріс з 38\% до 85\%, а активної частини - до 89,9\%. Основними перешкодами подолання цієї проблеми $\epsilon$ заниження більш ніж у 4 рази від ринкової вартості основних виробничих фондів (ОВФ). Це призводить до відповідного скорочення амортизаційних відрахувань. Порушений принцип простого відтворення ОВФ та необгрунтоване підвищення прибутків та нарахувань податків. Нажаль недостатня фінансова прозорість господарської діяльності i, як наслідок, незадовільна інвестиційна привабливість галузі, обмежують можливості залучення іноземних та приватних інвестицій у необхідних розмірах. Саме це пояснює збитковість пасажирських перевезень, яка за останні 10 років збільшилась у 3,5 рази і досягла році 3,3 млрд. грн. Негативним явищем $є$ те, що витрати на пасажирські перевезення на 50$60 \%$ покриваються за рахунок вантажних перевезень. Це $\epsilon$ наслідком необгрунтованих низьких пасажирських тарифів, які нажаль регулюються в «ручному» варіанті органами державної та місцевої влади, а також пільг на проїзд, які встановлені для 25 категорій громадян. Через відсутність механізму компенсації цих збитків рівень їх відшкодування у 2012 році склав лише 3,5\% від їх загального обсягу. Недостатнім $\epsilon$ рівень тарифів на вантажні перевезення, які у середньому в 2, 9 рази нижчі ніж у країнах СНД, та в 3-4 рази нижчі ніж в країнах Європи. Зменшення частки залізничного транспорту України в традиційних i перспективних транспортних послугах, недостатнє використання транзитного потенціалу, відсутність державної підтримки інноваційного розвитку галузі - далеко не повний перелік негативних факторів, що $є$ наслідком відсутності механізмів державного управління базовою галуззю.

Встановлено, що за обсягами транспортної роботи та порівняно з іншими країнами українські залізниці займають провідне місце у Європі. Їх вантажообіг складає 241 млрд. т-км., пасажирообіг близько 53 млрд. пас-км. на рік.

Аналіз пасажирообігу залізниць України свідчить про те, що в цілому динаміка його змінилась в залежності від багатьох факторів. Поперше, зростання пов'язано 3 додатковими пасажирськими маршрутами, впровадженням додаткових поїздів підвищенням їх комфортності; по-друге, значно збільшилась кількість відправлених пасажирів; по-третє, відбулось зростання i міжнародних пасажирських перевезень. Результат проведеного комплексного аналізу свідчить також про те, що Укрзалізниця втратила значний обсяг пасажирообігу за рахунок невикористання конкурентних переваг у ціновій політиці та зниженні якості наданих послуг.

Аналіз засвідчив те, що пасажирообіг на залізницях України щорічно незначно збільшується, а інвентарний парк пасажирських вагонів старіє на 350-400 вагонів. Нині цей парк досяг критичної межі 5414 одиниць. Таким чином, оновлення ОВФ не відповідає сучасним вимогам. 
Підраховано, що для закупівлі додатково 2200 вагонів, потрібно близько 18800 млн. грн. Національна економіка країни не має можливості виділити таку суму коштів, а залізниці не можуть накопичити відповідну суму за рахунок амортизації та прибутку. Для вирішення цієї проблеми доцільно запровадити комплекс заходів 3 метою ліквідації збитковості пасажирських перевезень, підвищення ефективності їх функціонування.

Оскільки цей проект потребує багато коштів, то необхідно розробити пропозиції та зробити науково-економічне обгрунтування його впровадження. Не вирішення цих проблем в умовах існуючих економічних підходів обумовлює необхідність реформування залізничного транспорту і передбачає принципові перетворення у сферах організаційних структур, майнових відносин, інвестиційно-модернізаційній, технологічній, фінансово-економічній, соціальнокадровій і нормативно-правовій. Зазначені проблеми обумовили необхідність розробки пропозицій щодо підвищення ефективності роботи пасажирських перевезень залізничного транспорту.

Авторами розроблено методику щодо оцінки впровадження високошвидкісного руху в економіку та управління національним господарством України, яка класифікована як елемент удосконалення.

У вигляді математичної моделі мережі ліній приймаємо неорієнтований граф 3 вершинами, відповідними містами, мають бути захопленими високошвидкісним пасажирським рухом поїздів, i ребрами графа, відповідними лініями мережі.

Якщо ми маємо за бажане «захопити» високошвидкісним рухом $N$ міст, то перелік ребер $E$ буде відповідати тій чи іншій мережі ліній залізниць.

Витрати на будівництво мережі можна обчислити за формулою:

$$
Z(E)=\sum_{e \in E} C(e)
$$

а час перебування пасажирів на шляху представити у вигляді:

$$
T(E)=\sum_{i=1}^{N-1} \sum_{j=i+1}^{N} \frac{P_{i j} R_{i j}(E)}{v_{i j}},
$$

де $C(e)$ - витрати на будівництво лінії, яка відповідає ребру графа $e$;

$$
R_{i j}(E) \text { - найкоротша відстань між }
$$

містами $i$ та $j$ на мережі, яка відповідає набору peбер $E$;

$$
P_{i j} \text { - пасажиро-потік між містами } i \text { та } j \text {; }
$$

$$
v_{i j} \text { - маршрутна швидкість між містами }
$$

$i$ та $j$.

Бажання зробити як можна меншими витрати засобів і часу приводить до задачі, яка представляє собою задачу векторної оптимізації, обмежену тим, що функції $Z(E)$ та $T(E)$ являють собою функції множин $E \subseteq \bar{E}$, де $\bar{E}$ - набір ребер, який відповідає повному графу.

$$
\left(\begin{array}{l}
Z(E) \\
T(E)
\end{array}\right) \rightarrow \min
$$

Відмітимо, що будемо розуміти під вирішенням задачі (1).

Визначення 1 . Мережу $E_{*}$ будемо називати ефективною, якщо будь-яка іiі варіація приводить до збільшенню $Z$ або $T$.

Визначення 2. Під вирішенням задачі (1) будемо розуміти множину $\varepsilon_{*}$, елементами якого являються ефективні мережі $E_{*}$.

Для розв'язання задачі (1) пропонується спеціальний математичний апарат, сутність якого полягає в тому, що започатковано узагальнене поняття варіації множин, яка дозволяє запропонувати конструкцію похідної функції множин і на іiі основі отримати необхідні умови екстремуму функції множин.

$$
\begin{gathered}
F_{1}(E)=\sum_{e \in E} l(e) \\
F_{2}(E)=\sum_{i=1}^{N-1} \sum_{j=i+1}^{N} P_{i j} R_{i j}(E)
\end{gathered}
$$

Очевидно, якщо ми введемо функції множин, то значно скоротимо інформаційне забезпечення задачі (3), а 3 іншої сторони має місце співвідношення:

$$
\begin{aligned}
& Z(E) \leq C F_{1}(E) ; \\
& T(E) \leq \frac{1}{v} F_{2}(E),
\end{aligned}
$$
довжини колії;

де $C$ - максимальна вартість одиниці

v - максимальна маршрутна швидкість.

Тоді, замість задачі (1) можна розглядати наступну задачу:

$$
\left(\begin{array}{c}
F_{1}(E) \\
F_{2}(E)
\end{array}\right) \rightarrow \min
$$

при $E \subseteq \bar{E}$.

Ключовим моментом розв'язку задачі (2) $\epsilon$ TEOPEMA. Якщо множина $E^{*}$ доставляє мінімум функції $F(E)$, то з необхідністю має місце: 


$$
\operatorname{sign}\left(\left.\bar{D}\right|_{\left\{B_{n}\right\}} F(E *)\right)=\operatorname{sign}\left(\left.\underline{D}\right|_{\left\{B_{n}\right\}} F(E *)\right) \leq 0,
$$

а у випадку, коли $\left(\left.\bar{D}\right|_{\left\{B_{n}\right\}} F(E *)\right)=\left(\left.\underline{D}\right|_{\left\{B_{n}\right\}} F(E *)\right)$, внутрішня похідна по мірі $\mu(\cdot)$

$$
\left.\frac{d F(E *)}{d \mu}\right|_{\left\{B_{n}\right\}} \leq 0
$$

де $\left\{B_{n}\right\}$ - послідовність множин, які сходяться до внутрішньої точки множин $E^{*}$;

$$
\left.\bar{D}\right|_{\left\{B_{n}\right\}} F(E *),\left.\underline{D}\right|_{\left\{B_{n}\right\}}(E *)-\quad \text { верхні } \quad \text { та }
$$

нижні похідні числа на послідовності $\left\{B_{n}\right\}$.

Взявши $N=18$ міст України, отримаємо 138 ефективних варіантів мережі ліній високошвидкісного руху пасажирських поїздів.

На підставі розробленої методики виявлено моделі впровадження високошвидкісного руху. Отримано оптимальний варіант мережі, яка має мінімальну відстань і охоплює міста, які мають населеність більш мільйона. Проведені розрахунки підкреслюють економічну доцільність впровадження високошвидкісного руху. Очікуваний обсяг відправлення пасажирів визначено у розмірі від одного до трьох існуючих відправлень пасажирів у дальньому залізничному сполученні.

Висновок. Таким чином, у статті виконано дослідження та запропоновані пропозиції, які розроблено на підставі науково обгрунтованих варіантів. Пропозиції мають забезпечити підвищення ефективності функціонування пасажирських перевезень в умовах реформування галузі. Результати дослідження засновані на методологічних підходах власних досліджень щодо визначення доцільності впровадження високошвидкісного руху із залученням вітчизняних та зарубіжних інвесторів до нового інноваційного проекту 3 метою отримання значного підвищення ефективності роботи національного господарства залізничного транспорту України. Запропоновані методичні підходи значно підвищують теорію економіки та управління національним господарством пасажирськими перевезеннями залізничним транспортом України.

\section{СПИСОК ЛІТЕРАТУРИ}

1 К. Макконел. Теория, практика и искусство управления / К. Макконел, А. Маршал, Кнорринг В.И. - М.: Изд. группа «НОРМА Инфра М», 1999. - 528 с.

2 Л. Рхад. Экономика, организация и менеджмент / Л. Рхад, Дж. Стігмець, В. Ойкне, А. Ханцен, М. Фрідмен. - СПб.: Экономическая школа, 1999. - 386 с.

3 Абалкин Л.І. Аналіз теорії Врума/ Абалкин Л.І., В.П. Бабич. - Режим доступу: http://www.socioego.ru

/teoriya/istoch/maddi/macclel sod.html

4 Лукинов И.И. Институциональная динамика и теория реформ/ Лукинов И.И. // Эволюционная экономика и «мэйнстрим». - М.: Наука, 2002. - 298 с.

5 Бєлов I.В. Экономика железнодорожного транспорта/ Бєлов I.В., Галабурда В.Г., Трихунков М.Ф., Мандриков М.Є., Терьошина Н.В, Смєхова Н.Г., Толкачева М.М, Царьов Р.М. - М.:МИИТ, 1995. - 340 с.

6 Соболев Ю.В. Стратегия предприятия и стратегический менеджмент/ Соболев Ю.В., Дейнека О.Г., Дикань В.Л., Позднякова Л.О. - ООО «Олант», 2002. 416c.

7 Бараш Ю.С. Реформування пасажирського господарства залізничного транспорту України. // Збірник наукових праць Київського університету економіки і технологій транспорту Міністерства транспорту України: Серія «Економіка i управління».- Вип. 3.- К.: КУЕTТ. - 2003. - С. 74-80.

8 Мукминова Т.О. Модель высокоскоростной сети на железных дорогах Украины/ Мукминова Т.О.// Вісник ДНУЗТ им. В.Лазаряна. - Дніпропетровськ . - 2004. Вип. №1. - C. 103-109.

Рецензент д.е.н., професор УкрДУЗТ Позднякова Л.О. Експерт редакційної колегії к.е.н., дочент УкрДУЗТ Боровик Ю.Т. 